\title{
PERSEPSI MAHASISWA DIPLOMA III MANAJEMEN PERUSAHAAN UNIVERSITAS ISLAM NEGERI SULTAN SYARIF KASIM RIAU TERHADAP FAKTOR - FAKTOR PEMICU KECURANGAN
}

\author{
Ferizal Rachmad
}

abstract

The purpose of this research is to know the difference in student perceptions of male and female college students Diploma III Management Company University of Sultan Syarif Kasim State Islamic Riau against the trigger factors of cheating (apressure, fraud, opportunity, and rationalization) of the sample in this study using a purposive sampling of 100 students majoring in DIII MP FEKONSOS Uinen Sultan Syarif Kasim Riau which consist of 46 male students and 54 people the female student. From the results obtained that first, there is a difference of perception significantly between student-sex men - men and women-sex against the pressure, and the conclusion that there is a difference of perception about understanding the pressure that is accepted by the perpetrator of the fraud. Second, that there is a difference of perception significantly between student-sex men - men and women-sex against opportunity,

\begin{abstract}
ABSTRAKSI
Tujuan penelitian ini adalah untuk mengetahui perbedaan persepsi mahasiswa laki-laki dan mahasiswa perempuan Diploma III Manajemen Perusahaan Universitas Islam Negeri Sultan Syarif Kasim Riau terhadap faktor-faktor pemicu kecurangan (apressure, fraud, opportunity, dan rationalization)

Sampel dalam penelitian ini menggunakan purposive sampling yang berjumlah 100 orang Mahasiswa Jurusan DIII MP FEKONSOS Universitas Islam Negeri Sultan Syarif Kasim Riau yang terdiri dari 46 mahasiswa laki-laki dan 54 orang mahasiswa perempuan.

Dari hasil penelitian diperoleh bahwa pertama, terdapat perbedaan persepsi secara signifikan antara mahasiswa berjenis kelamin laki - laki dan berjenis kelamin perempuan terhadap pressure,dan diperoleh kesimpulan bahwa terdapat perbedaan persepsi tentang pemahaman tekanan yang diterima oleh pelaku kecurangan. Kedua, bahwa terdapat perbedaan persepsi secara signifikan antara mahasiswa berjenis kelamin laki - laki dan berjenis kelamin perempuan terhadap opportunity, dan diperoleh kesimpulan bahwa terdapat perbedaan persepsi tentang pemahaman kesempatan yang dilakukan oleh pelaku kecurangan. Ketiga bahwa tidak terdapat perbedaan persepsi secara signifikan antara mahasiswa berjenis kelamin laki - laki dan berjenis kelamin perempuan terhadap rasionalization, dan diperoleh kesimpulan bahwa terdapat kesamaan persepsi tentang pemahaman rasionalisasi yang dapat
\end{abstract}


diambil oleh pelaku kecurangan. Keempat, bahwa tidak terdapat perbedaan persepsi secara signifikan antara mahasiswa berjenis kelamin laki - laki dan berjenis kelamin perempuan terhadap froud, dan diperoleh kesimpulan bahwa terdapat kesamaan persepsi tentang pemahaman kecurangan oleh pelaku kecurangan.

\section{Kata Kunci : Pemicu kecurangan, pressure, opportunity, rationalization, dan fraud}

\section{PENDAHULUAN}

\subsection{Latar Belakang}

Manusia sebagai makhluk individu dan sosial tentunya memilki beragam kebutuhan dan keinginan yang harus di penuhi. Maslow (1993) dalam teorinya mendefinisikan kebutuhan manusia menjadi lima. Pertama kebutuhan psikologis manusia yaitu kebutuhan akan makanan, minuman, tempat berlindung (rumah) dan pertolongan dari kesusahan. Kedua kebutuhan akan keamanan yaitu kebutuhan manusia akan kebebasan dari ancaman atau keamanan atas kejadian atau lingkungan yang mengancam. Ketiga, kebutuhan akan rasa memiliki, social, dan kasih sayang yang meliputi kebutuhan akan persahabatan, persatuan, interaksi dan kasih sayang. Keempat, kebutuhan manusia akan penghargaan baik terhadap diri sendiri maupun dari orang lain. Terakhir, kebutuhan akan menunjukkan diri yang sebenarnya yaitu kebutuhan manusia untuk memenuhi diri sendiri dengan memaksimalkan penggunaan dari kemampuan, keahlian,dan potensi diri.

Beragam kebutuhan di atas merupakan motivator bagi seseorang untuk melakukan suatu tindakkan yang nyata agar kebutuhannya terpenuhi. Sayangnya, tidak semua oraqang dapat memenuhi kebutuhannya dengan cara yang dibenarkan. Adanya hambatan - hambatan seperti perbedaan kepentingan, tekanan dari lingkungan keluarga maupun kerja, gaji yang rendah dan sedikitnya penghargaan yang diterima memotivasi seseorang untuk mengambil jalan pintas dengan melakukan kecurangan.

Kecurangan merupakan bentuk dari ketidak jujuran manusia. Namun, melakukan kecurangan kadang menjadi suatu pilihan bagi sebagian orang yang berada dalam kondisi terdesak oleh besarnya hambatan - hambatan yang harus dihadapi.

Situasi seperti ini mungkin saja terjadi di tengah lingkungan kita khususnya terdapat sebagian orang yang merasa bahwa kejujuran itu bersifat situasional. Bahkan ada pula orang yang menganggap bahwa kecurangan itu sebagai suatu kebutuhan (Callahan, 2004 dalam Vorhoff, 2004).

Di Indonesia, beragam praktek kecurangan sering terjadi dan kita temukan hanya saja lebih kita kenal dengan istilah korupsi. Maraknya kasus korupsi dan praktek - praktek kecurangan tersebut tentu saja menarik perhatian yang sangat besar dari peneliti. Peneliti sebagai dosen dan salah satu elemen masyarakat merasa bahwa para mahasiswa seharusnya peka dan tidak boleh mentup mata terhadap permasalahan ini. 
Kita tidak hanya mengetahui tetapi juga memahami tentang kecurangan dan isu - isu atau permasalahan mengenai hal tersebut.

Pemahaman dan tingkat kepekaan mahasiswa mengenai hal ini tentu saja dapat mempengaruhi persepsi mahasiswa mengenai faktor-faktor pemicu kecurangan. Persepsi mahasiswa terhadap faktor - faktor pemicu kecurangan ini menjadi hal penting untuk dapat membantu dalam pemberantasan kasus - kasus kecurangan yang terjadi di sekitar mereka. Seandainya saja, seluruh element masyarakat termasuk mahasiswa memiliki persepsi yang sama bahwa kecurangan merupakan hal yang tidak dapat di benarkan dan mereka perduli akan hal ini maka berbagai kasus kecurangan di sekitar kita akan lebih mudah terungkap dan ditindaklanjuti atau diberantas.

Jurusan Diploma III Manajmen Perusahaan Fakultas Ekonomi Universitas Islam Negeri Sultan Syarif Kasim Riau memegang peranan yang penting dalam pembentukkan persepsi mahasiswa. Tempat ini dapat menjadi media untuk penyampaian informasi dan pembelajaran mengenai isu - isu dan hal yang terkait dengan kecurangan bagi mahasiswa.

Jika para mahasiwa mandapatkan pengetahuan dan pemahaman yang cukup mengenai kecurangan selama di bangku kuliah maka seharusnya mereka akan memiliki suatu persepsi yang sama terhadap hal tersebut yaitu bahwa kecurangan merupakan hal yang tidak dapat dibenarkan.

Akan tetapi, pengetahuan yang diberikan selama kuliah mungkin tidak mencukupi dan patut diakui bahwa tingkat pemahaman dan kepekaan mahasiswa dapat berbeda antara satu dengan yang lainnya. Akibat adanya persepsi mahasiswa terhadap faktor - faktor pemicu kecurangan mungkin saja berbeda satu dengan yang lainnya. Oleh karena itu, penelitian ini diberi judul : "PERSEPSI MAHASISWA DIPLOMA III MANAJEMEN PERUSAHAAN UNIVERSITAS ISLAM NEGERI SULTAN SYARIF KASIM RIAU TERHADAP FAKTOR - FAKTOR PEMICU KECURANGAN".

\subsection{Rumusan Masalah}

Berdasarkan uraian pada latar belakang mengacu pada judul dan tema penelitian maka permasalahan yang dibahas dalam penelitian ini adalah:

1. Apakah terdapat perbedaan persepsi antara mahasiswa laki-laki dan mahasiswa perempuan Diploma III Manajemen Perusahaan Universitas Islam Negeri Sultan Syarif Kasim Riau terhadap pressure?

2. Apakah terdapat perbedaan persepsi antara mahasiswa laki-laki dan mahasiswa perempuan Diploma III Manajemen Perusahaan Universitas Islam Negeri Sultan Syarif Kasim Riau terhadap opportunity?

3. Apakah terdapat perbedaan persepsi antara mahasiswa laki-laki dan mahasiswa perempuan Diploma III Manajemen Perusahaan Universitas Islam Negeri Sultan Syarif Kasim Riau terhadap rationalizations?

4. Apakah terdapat perbedaan persepsi antara mahasiswa laki-laki dan mahasiswa perempuan Diploma III Manajemen Perusahaan Universitas Islam Negeri Sultan Syarif Kasim Riau terhadap fraud? 


\subsection{Tujuan Penelitian}

Adapun tujuan dari penelitian ini adalah sebagai berikut:

1. Untuk mengetahui perbedaan persepsi mahasiswa laki-laki dan mahasiswa perempuan Diploma III Manajemen Perusahaan Universitas Islam Negeri Sultan Syarif Kasim Riau terhadap pressure.

2. Untuk mengetahui perbedaan persepsi mahasiswa laki-laki dan mahasiswa perempuan Diploma III Manajemen Perusahaan Universitas Islam Negeri Sultan Syarif Kasim Riau terhadap opportunity.

3. Untuk mengetahui perbedaan persepsi mahasiswa laki-laki dan mahasiswa perempuan Diploma III Manajemen Perusahaan Universitas Islam Negeri Sultan Syarif Kasim Riau terhadap rationalizations.

4. Untuk mengetahui perbedaan persepsi mahasiswa laki-laki dan mahasiswa perempuan Diploma III Manajemen Perusahaan Universitas Islam Negeri Sultan Syarif Kasim Riau terhadap fraud.

\section{TELAAH PUSTAKA}

\subsection{Persepsi}

Menurut Kotler ( 2004 ), persepsi adalah proses yang digunakan seseorang individu untuk memilih, mengorganisasi, dan menginterorientasi masukan - masukan informasi guna menciptakan gambaran dunia yang memiliki arti.

Dalam kamus besar Bahasa Indonesia persepsi didefinisikan sebagai : 1) tanggapan (penerimaan) langsung dari sesuatu, 2) proses seseorang mengetahui beberapa hal melalui panca inderanya.

Persepsi memiliki dua aspek yaitu : pengakuan pola (pattern recognition) dan perhatian (attention). Pengakuan pola mengikuti identifikasi serangkaian stimulus yang kompleks, yang dipengaruhi oleh konteks yang dihadapi dan pengalaman masa lalu.

Sementara, perhatian merupakan kosentrasi dari aktivitas mental, yang melibatkan pemprosesan lebih lanjut atas situasi stimuli dan dalam waktu bersamaan tidak memindahkan stimuli yang lain.

Sementara itu, istilah lain yang relevan dengan penelitian ini adalah persepsi sosial, yaitu proses menangkap arti objek - objek sosial yang dialami dalam suatu lingkungan Mulyana (2004).

Berikut ini adalah beberapa prinsip penting mengenai persepsi sosial :

1. Persepsi berdasarkan pengalaman.

2. Persepsi bersifat selektif.

3. Persepsi bersifat dugaan.

4. Persepsi bersifat evaluatif.

5. Persepsi bersifat kontekstual.

Menurut Samovar dan porter, persepsi juga bisa mengalami kekeliruan dan kegagalan, diantaranya adalah : 
1. Kesalahan Atribusi.

2. Efek Halo

3. Stereotip

4. Prasangka

5. Gegar Budaya

Menurut Kotler (2004), orang dapat memiliki persepsi berbeda atas objek yang sama karena dua proses persepsi, yaitu:

1. Perhatian Selektif.

2. Distorsi Selektif

Jadi dapat disimpulkan bahwa persepsi merupakan suatu proses kognitif yang dialami setiap orang dalam memahami setiap informasi yang datang dari lingkungannya melalui panca inderanya. Oleh sebab itu setiap orang akan memberikan respon yang berbeda dari setiap stimulus yang datang dari lingkungan.Jadi setiap individu yang berbeda akan merespon akan merespon sesuatu hal yang sumbernya sama secara berbeda pula.

\subsection{Kecurangan (Fraud)}

Kecurangan adalah suatu istilah yang digunakan untuk mengartikan tindak kejahatan yang menggunakanam akal pikiran manusia untuk menipu, menyembunyikan kebenaran diri, dan melakukan kelicikan lainnya kepada orang lain agar memperoleh mafaat financial darinya dan merugikan orang tersebut. Menurut U.S Supreme Court (Weirich, 2003), elemen - elemen kecurangan meliputi:

1. Seorang individu atau sebuah organisasi yang dengan sengaja membuat gambaran yang tidak benar mengenai fakta maupun kejadian yang penting dimana gambaran tersebut dibuat agar dapat diandalkan oleh korbannya.

2. Gambaran yang tidak benar tersebut dipercaya oleh korban.

Korban mengandalkan dan bertindak berdasarkan gambaran yang salah.berpendapat bahwa kecurangan merupakan serangkaian irregularities dan illegal acts yang dilakukan untuk menipu atau memberikan gambaran kekeliruan terhadap pihak lain yang dilakukan pihak intern dan pihak extern suatu organisasi dengan tujuan menguntungkan diri sendiri dan orang lain dengan merugikan orang lain.

Menurut Weirich (2003) dan Albrecht (2003), faktor - faktor pemicu terjadinya kecurangan ada empat:

1. Adanya Tekanan yang Diterima oleh Pelaku Kecurangan.

Tekanan ini dapat berupa:
a. Tekanan Keuangan
b. Tekanan Sekunder
c. Tekanan Pekerjaan
d. Tekanan Lainnya

2. Adanya Kesempatan yang Dapat Diambil oleh Pelaku Kecurangan.

3. Adanya Rasionalisasi yang Salah oleh Pelaku.

4. Adanya Kecurangan yang Dilakukan oleh Pelaku Kecurangan.

Keempat faktor-faktor pemicu ini dapat digambarkan dalam segitiga berikut ini: 


\section{FAKTOR-FAKTOR PEMICU KECURANGAN}

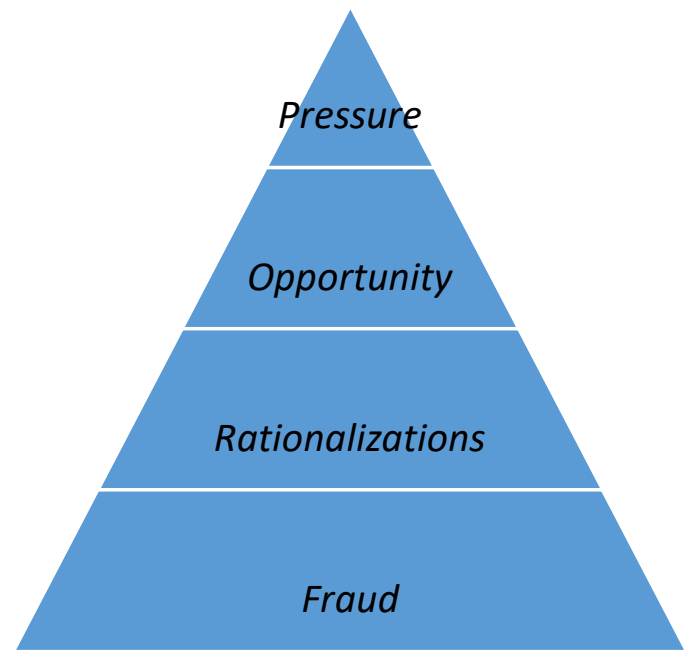

Gambar 1.1

Sumber : Alison (2006)

Menurut Albercht (2003), pelaku kecurangan biasanya memiliki karakteristik yang sama dengan kebanyakan orang pada umumnya. Bahkan, sebagian besar pelaku kecurangan justru tampak seperti orang -orang yang berperilaku jujur. Mereka umumnya memiliki pendidikan yang tinggi dan lebih beragama, sedikit atau bahkan tidak memiliki catatan kejahatan, dan bukan pecandu alkohol maupun obat terlarang. Berdasarkan karekteristik tersebut, sebagian besar karyawan, pelanggan, vendor,dan rekan bisnis merupakan pihak - pihak yang memenuhi karakteristik tersebut sehingga mereka memiliki kemungkinan untuk melakukan kecurangan.

Menurut Association of Certified Fraud Examiner (ACFE) dalam Amrizal (2004) mengelompokkan bentuk kecurangan menjadi tiga kategori, yaitu:

1. Penyalahgunaan Asset

Bentuk kecurangan dalam penyalah gunaan asset misalnya :

a. Penggelapan (Embezzlement)

Penggelapan adalah suatu bentuk kecurangan dengan menukarkan milik pribadinya berdasarkan kerjasama yang dapat dipercaya. Elemen - elemen dari penggelapan itu adalah: Pelaku mengambil atau mengubah, tanpa pengetahuan atau persetujuan milik, uang atau asset milik pihak lain, dan yang dipercayakan kepada pelaku.

Contoh dari penggelapan ini adalah kiting dan lapping. Kiting terjadi ketika bank memperkenankan penarikan atas cek yang didepositokan oleh nasabah namun dana tersebut sebenarnya belum ada di bank tersebut. Sementara itu, lapping adalah penggunaan atas uang yang diterima dari pembayaran piutang untuk menutupi pencurian tas kas. 


\section{b. Larceny}

Larceny didefinisikan sebagai cara pengambilan uang atau asset yang salah dengan maksud mengkonversikan atau mencabut nama pemilik atas hak milik dan hak guna. Elemen- elemen dari larceny adalah:

i. Mengambil atau membawa;

ii. Uang atau asset pihak lain;

iii. Tanpa sepengetahuan pemiliknya; dan

iv. Dengan maksud menghilangkan hak milik dan hak guna pemilik.

2. Kecurangan atas Laporan Keuangan

Kecurangan laporan keuangan dapat didefinisikan sebagai kecurangan yang dilakukan oleh manajemen dalam bentuk salah saji material laporan keuangan yang merugikan investor dan kreditor. Kecurangan ini dapat bersifat financial maupun non financial. Adapun bentuk - bentuk kecurangan atas laporan keuangan adalah sebagai berikut:

a. Penyembunyian atas fakta yang Material.

Tindakkan kecurangan yang termasuk penyembunyian atas fakta yang material adalah jika pelaku kecurangan itu mempunyai kewajiban untuk melakukan pengungkapan. Elemen - elemen penting dari kecurangan ini yaitu :

i. Pelaku memiliki pengetahuan;

ii. Atas fakta yang material;

iii. Pelaku memiliki kewajiban untuk mengungkapkan

iv. Dan gagal untuk melakukan hal tersebut;

v. Dengan maksud untuk menyesatkan atau menipu pihak lain.

b. Salah Saji Material

Pada umumnya elemen-elemen dari kecurangan ini adalah :

i. Adanya salah saji yang material;

ii. Pelaku mengetahui adanya kesalahan tersebut;

iii. Korban menaruh kepercayaan pada laporan keuangan yang salah

iv. Korban di rugikan.

Adapun bentuk - bentuk dari salah saji material diantaranya adalah kecurangan atas salah pernyataan atau klaim yang salah (false statemens and false clims) dan kecurangan melalui surat atau kabel (mail fraud and wire fraud).

False statement and false claims adalah bentuk kecurangan yang terjadi ketika pelaku mengetahui secara sadar dan sengaja memalsukan fakta yang material atau membuat kesalahan atau representasi fiktif dan mendokumentasikan klaim yang salah sehingga mengakibatkan kerugian secara financial pada pihak yang menjadi objek dari kecurangan. Mail fraud and Wire fraud terjadi ketika seseorang melakukan tindak kecurangan dengan menggunakan telepon maupun surat untuk mendiskusikan atau mengirim dan menerima korespondensi atau dokumen.

\section{Korupsi}

Tindakan kecurangan yang termasuk korupsi terdiri dari:

a. Breach of Fiduciary Duty 
Breach of Fiduciary duty terjadi ketika seseorang yang dipekerjakan dan memiliki kewajiban kepada suatu perusahaan atau orang lain, melakukan tindakan yang tidak memberikan keuntungan financial bagi perusahaan atau orang lain tersebut. Adapun kewajiban dari orang tersebut meliputi kewajiban untuk memberi perhatiaan kepada perusahaan atau orang yang telah mempekerjakannya.

b. Konflik Kepentingan

Konflik kepentingan terjadi ketika seseorang atau perusahaan melakukan suatu tindakkan atas nama pribadi maupun perusahaan dan memiliki bias yang tersembunyi atau kepentingan pribadi dalam aktivitas yang dilakukannya. Dimana kepentingan pribadinya itu berlawanan dengan kepentingan individu atau perusahaan yang seharusnya dan tidak diketahui oleh pihak lain selain dirinya sendiri atau perusahaan tersebut. Konflik kepentingan meliputi:

1. Seseorang atau pihak memiliki kepentingan atas sebuah transaksi;

2. Dimana kepentingan itu berlawanan dengan yang seharusnya; dan

3. Tanpa pengungkapan maupun pengakuan dari pelaku

c. Suap

Suap adalah suatu tindakkan memberi, menerima, menawarkan atau mengumpulkan "segala sesuatu yang bernilai", untuk mempengaruhi pihak tertentu dalam menilai kinerja atau kegagalan perusahaan. Yang mana Elemen - elemen suap itu adalah: memberikan penawaran, sesuatu yang bernilai, dan mempengaruhi pihak lain.

Suap terbagi kedalam tiga bentuk yaitu:

1. Suap dalam bisnis.

Suap dalam bisnis adalah suatu tindakkan memberi, menerima, menawarkan atau mengumpulkan "segala sesuatu yang bernila" untuk mempengaruhi keputusan bisnis tanpa sepengetahuan korban (biasanyan perusahaan bisnis).

2. Illegal gratuity.

Illegal gratuity adalah suatu tindakkan memberi, menerima, menawarkan atau mengumpulkan "segala sesuatu yang bernilai" setelah adanya fakta untuk atau karena tindakkan yang diambil oleh pihak lain.

3. Economic extortion.

Economic Extortin adalah suatu tindakkan yang terjadi ketika seseorang atau perusahaan mendapatkan sesuatu dari orang atau perusahaan lain yang merupakan official office dengan memberikan tekanan atau memanfaatkan ketakutan atas kerugian secara ekonomi maupun fiscal.

Di Indonesia, bentuk kecurangan (fraud) yang sering kita dengar adalah korupsi. Namun, istilah di Indonesia memiliki definisi yang lebih luas dari pada yang dimaksudkan oleh Association of Certified Fraud Examiner (ACFE) seperti diatas. 
Ada tiga puluh macam tindak kecurangan yang termasuk korupsi dan dua puluh diantaranya merupakan tindak kecurangan yang digunakan dalam penelitian ini.

Berikut adalah penjelasan dari keduapuluh macam tindak korupsi tersebut berdasarkan UU. No 31 Tahun 1999 jo. UU No.20 Thun 2001 (komisi pemberantasan korupsi, 2006) :

1. Korupsi yang terkait dengan kerugian keuangan Negara

Dua bentuk tindakkan kecurangan yang termasuk dalam kategori ini adalah:

a. Melawan hukum untuk memperkaya diri dan dapat merugikan keuangan

Negara menurut pasal 2, setiap orang yang memperkaya diri sendiri, orang lain atau suatu korporasi dengan cara melawan hukum dan dapat merugikan keuangan Negara atau perekonomian Negara termasuk dalam tindakkan korupsi.

b. Menyalah gunakan kewenangan untuk menguntungkan diri sendiri dan dapat merugikan keuangan Negara pasal 3 menyatakan bahwa setiap orang dengan tujuan menguntungkan diri sendiri atau orang lain atau sarana yang ada padanya karena jabatan atau kedudukan sehingga dapat merugikan keuangan Negara atau perekonomian Negara termasuk dalam tindak korupsi.

2. Korupsi yang terkait dengan suap menyuap

Empat bentuk tindak kecurangan yang termasuk dalam kategori ini yaitu:

a. Menyuap pegawai negeri

Dalam pasal 5 ayat (1) huruf a disebutkan bahwa setiap orang yang memberi sesuatu atau menjanjikan sesuatu kepada pegawai negeri atau penyelenggara. Negara dengan maksud supaya berbuat atau tidak berbuat sesuatu dalam jabatannya sehingga bertentangan dengan kewajibannya adalah suatu tindak korupsi.

Selain itu, pasal 5 ayat (1) huruf b menyebutkan bahwa setiap orang yang memberi sesuatu kepada pegawai negeri atau penyelenggara Negara karena atau berhubungan dengan sesuatu yang bertentangan dengan kewajiban, dilakukan atau tidak dilakukan dalam jabatannya merupakan tindak korupsi.

b. Memberi hadiah kepada pegawai negeri karena jabatannya.

Dalam pasal 13 disebutkan bahwa setiap orang yang memberi hadiah atau janji kepada pegawai negeri dengan mengingat kekuasaan atau wewenang yang melekat pada jabatan kedudukannya, atau oleh pemberi hadiah atau janji dianggap melektakan pada jabatan atau kedudukan tersebut merupakan tindak korupsi.

c. Pegawai negeri menerima suap.

Pasal 5 ayat (2) menyatakan bahwa pegawai negeri atau penyelenggara Negara yang menerima pemberian atau janji sebagaimana dimaksud dalam Pasal 5 ayat (1) huruf a atau b merupakan tindakkan korupsi.Selain itu Pasal 12 huruf a menyatakan bahwa pegawai negeri atau penyelenggara Negara yang menerima hadiah atau janji, padahal diketahui atau patut diduga bahwa hadiah atau janji tersebut diberikan untuk menggerakkan agar melakukan atau tidak melakukan 
sesuatu dalam jabatannya, yang bertentangan dengan kewajibannya termasuk tindak korupsi.

Ditambah lagi, Pasal 12 huruf b yang menyatakan bahwa pegawai negeri atau penyelenggara Negara yang menerima hadiah, padahal diketahui atau patut diduga bahwa hadiah tersebut diberikan sebagai akibat atau disebabkan karena telah melakukan atau tidak melakukan sesuatu dalam jabatannya yang bertentangan dengan kewajibannya merupakan tindak korupsi.

d. Pegawai negeri menerima hadiah yang berhubungan dengan jabatannya.

Berdasarkan pasal 11, pegawai negeri atau penyelenggara Negara yang menerima hadiah atau janji padahal diketahui atau patut diduga, bahwa hadiah atau janji tersebut diberikan karena kekuasaan atau kewenangan yang berhubungan dengan jabatannya dan menurut pikiran orang yang memberikan hadiah atau janji tersebut ada hubungan dengan jabatannya termasuk tindak korupsi.

3. Korupsi yang terkait dengan penggelapan dalam jabatan.

Lima bentuk tindak kecurangan yang termasuk dalam kategori ini yaitu:

a. Pegawai negeri menggelapkan uang atau membiarkan penggelapan.

Menurut pasal 8, pegawai negeri atau orang selain pegawai negeri yang ditugaskan menjalankan suatu jabatan umum secara terus - menerus atau untuk sementara waktu dengan sengaja menggelapkan uang atau surat berharga yang disimpan karena jabatannya, atau membiarkan uang atau surat berharga tersebut diambil atau digelapkan oleh orang lain, atau membantu dalam melakukan perbuatan tersebut merupakan tindak korupsi.

b. Pegawai negeri memalsukan buku untuk memeriksa administrasi.

Dalam pasal 9 menyatakan bahwa pegawai negeri atau orang selain pegawai negeri yang ditugaskan untuk menjalankan suatu jabatan umum secara terus menerus atau untuk sementara waktu dengan sengaja memalsukan buku buku atau daftar - daftar yang khusus untuk pemeriksaan administrasi termasuk tindak korupsi.

c. Pegawai negeri membiarkan orang lain merusak bukti.

Dalam pasal 10 huruf $b$ disebutkan bahwa pegawai negeri atau orang selain pegawai negeri yang ditugaskan menjalankan suatu jabatan umum secara terus - menerus atau untuk sementara waktu dengan sengaja membiarkan orang lain menghilangkan, menghancurkan, merusakkan, atau membuat tidak dapat dipakai barang, akta, surat atau daftar sebagaimana disebutkan pada Pasal 10 huruf a merupakan tindak korupsi.

d. Pegawai negeri membantu orang lain merusakkan bukti.

Pasal 10 huruf c menyatakan bahwa pegawai negeri atau orang selain pegawai negeri yang ditugaskan menjalankan suatu jabatan umum secara terus menerus atau untuk sementara waktu dengan sengaja membantu orang lain menghilangkan, menghancurkan, merusakkan, atau membuat tidak dapat dipakai barang, akta, surat atau daftar sebagaimana disebut pada Pasal 10 huruf a termasuk tindak korupsi. 
4. Korupsi yang terkait dengan perbuatan pemerasan

Dua bentuk tindak kecurangan yang termasuk dalam kategori ini adalah :

a. Pegawai negeri memeras

Pasal 12 huruf e menyatakan bahwa pegawai negeri atau penyelenggara Negara yang dengan maksud menguntungkan diri sendiri atau orang lain secara melawan hukum, atau dengan menyalahgunakan kekuasaanya memaksa seseorang memberikan sesuatu, membayar, atau menerima bayaran dengan potongan,atau untuk mengerjakan sesuatu bagi dirinya sendiri merupakan tindak korupsi.

Selain itu, Pasal 12 huruf g menyatakan bahwa pegawai negeri atau penyelenggara Negara yang pada waktu menjalankan tugasnya, meminta atau menerima pekerjaan, atau penyerahan barang, seolah - olah merupakan hutang kepada dirinya, padahal diketahui bahwa hal tersebut bukan merupakan hutang ini termasuk dalam tindakkn korupsi.

b. Pegawai negeri memeras pegawai lain

Dalam Pasal 12 huruf $\mathrm{f}$ disebutkan bahwa pegawai negeri atau penyelenggara Negara yang pada waktu menjalankan tugas, meminta, menerima atau memotong pembayaran kepada pegawai negeri atau penyelenggara yang lain atau kepada kas umum, seolah - olah pegawai negeri atau penyelenggara Negara yang lain atau kas umu tersebut mempunyai hutang kepadanya, padahal diketahui bahwa hal tersebut bukan merupakan hutang termasuk tindak korupsi.

5. Korupsi yang terkait dengan perbuatan curang

Dua bentuk tindak kecurangan yang termasuk dalam kategori ini adalah :

a. Pemborong berbuat curang

Pasal 7 ayat (1) huruf a menyatakan bahwa pemborong, ahli bangunan yang ada pada waktu membuat bangunan, atau penjual bahan bangunan yang ada pada waktu menyerahkan bahan bangunan, melakukan perbuatan curang yang dapat membahayakan keamanan orang lain atau barang, atau keselamatan Negara dalam waktu perang merupakan tindak korupsi.

b. Pengawas proyek membiarkan adanya perbuatan curang

Pasal 7 ayat (1) huruf b menyatakan bahwa setiap orang yang bertugas mengawasi pembangunan atau penyerahan bahan bangunan, sengaja membiarkan perbuatan curang sebagaimana dimaksud dalam pasal 7 ayat (1) huruf a merupakan tindak korupsi.

6. Korupsi yang terkait dengan benturan kepentingan dalam pengadaan

Tindak kecurangan yang termasuk dalam kategori ini adalah pegawai negeri yang turut serta dalam pengadaan yang diurusnya.hal ini diatur dalam Pasal 12 huruf I yang menyatakan bahwa pegawai negeri atau penyelenggara Negara baik langsung maupun tidak langsung dengan sengaja turut serta dalam pemborongan, pengadaan atau 
penyewaan yang pada saat itu dilakukan perbuatan untuk seluruh atau sebagian di tugaskan untuk mengurus atau mengawasinya merupakan tindakkan korupsi.

\subsection{Variabel dan Model Penelitian.}

Dalam penelitian ini terdapat dua variabel yaitu variabel indenpenden dan variabel dependen.

Variabel indenpenden dalam penelitian ini adalah mahasiswa akuntansi berjenis kelamin laki-laki dan berjenis kelamin perempuan. Yang menjadi Variabel Dependen adalah kecurangan.

Model gambar yang digunakan dalam penelitian ini adalah sebagai berikut:

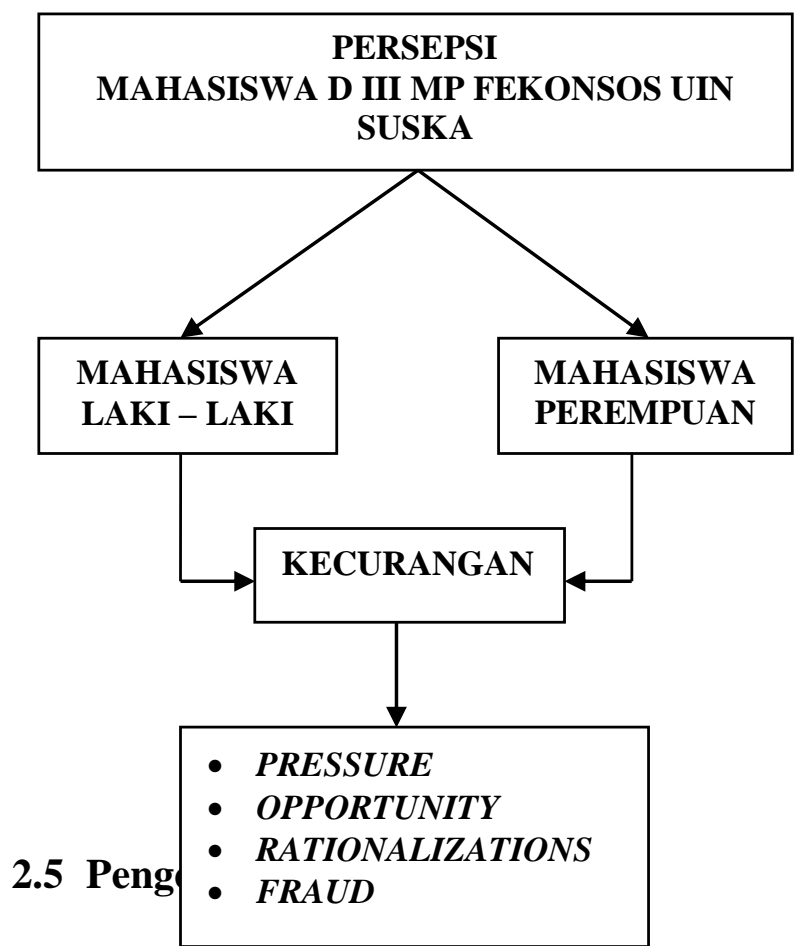

Berdasarkan rumusan masalah beberapa penelitian terdahulu dan tinjauan pustaka seperti diuraikan sebelumnya maka hipotesis dalam penelitian ini adalah:

Ha1 : Terdapat perbedaan persepsi antara mahasiswa Jurusan Diploma III Manajemen Perusahaan Fakultas Ekonomi Universitas Islam Negeri Sultan Syarif Kasim Riau yang berjenis kelamin laki - laki dan berjenis kelamin perempuan terhadap pressure.

Ha2 : Terdapat perbedaan persepsi antara mahasiswa Jurusan Diploma III Manajemen Perusahaan Fakultas Ekonomi Universitas Islam Negeri Sultan Syarif Kasim Riau yang berjenis kelamin laki - laki dan berjenis kelamin perempuan terhadap opportunity.

Ha3 : Terdapat perbedaan persepsi antara mahasiswa Jurusan Diploma III Manajemen Perusahaan Fakultas Ekonomi Universitas Islam Negeri Sultan 
Syarif Kasim Riau yang berjenis kelamin laki - laki dan berjenis kelamin perempuan terhadap rationalization.

Ha4 : Terdapat perbedaan persepsi antara mahasiswa Jurusan Diploma III

Manajemen Perusahaan Fakultas Ekonomi Universitas Islam Negeri Sultan Syarif Kasim Riau yang berjenis kelamin laki - laki dan berjenis kelamin perempuan terhadap fraud.

\section{BAB III METODE PENELITIAAN}

\subsection{Jenis Penelitian.}

Inti dari pelitian ini adalah mencari tahu apakah terdapat perbedaan persepsi antara mahasiswa Jurusan Diploma III Fakultas Ekonomi dan Ilmu Sosial Universitas Islam Negeri Sultan Syarif Kasim Riau yang berjenis kelamin laki - laki dan berjenis kelamin perempuan terhadap faktor-faktor pemicu kecurangan. Oleh karena itu, penelitian ini menguji hipotesis yang telah dikembangkan melalui teori - teori yang sudah ada. Jadi jenis penelitiaan ini termasuk riset pengujiaan hipotesis.

Sementara itu metode yang digunakan dalam penelitian ini adalah metode kuantitatif. Metode kuantitatif adalah melakukan perhitungan terhadap data yang diperoleh untuk melakukan suatu pengukuran tertentu guna mengetahui persepsi mahasiswa akuntansi. Tujuan dari metode ini adalah untuk mencari hubungan antara variabel - variabel kemudian hubungan - hubungan itu di uji satu sama lainnya selanjutnya mengumpulkan informasi secara rinci yang melukiskan gejala yang ada. Mengidentifikasi masalah serta memeriksa kondisi dan praktek - praktek yang berlaku, membuat perbandingan atau evaluasi, dan menentukan apa yang dilakukan orang lain dalam menghadapi masalah yang sama dan belajar dari pengalaman mereka untuk menetapkan rencana dan keputusan pada waktu yang akan datang.

\subsection{Lokasi dan Waktu Penelitian.}

Penelitian ini dilakukan di Perguruan Tinggi Universitas Islam Negeri Sultan Syarif Kasim Riau yaitu mahasiswa dan mahasiswi D3 MP pada bulan Agustus s/d Nopember 2016.

\subsection{Populasi dan Sampel}

1. Populasi.

Populasi dalam penelitian ini adalah mahasiswa dan mahasiswi D3 MP Universitas Islam Negeri Sultan Syarif Kasim Riau Semester III dan V sebanyak 119 orang.

\section{Teknik Pengambilan Sampel.}

Untuk mengetahui dan menentukan sampel dari penelitiaan ini peneliti menggunakan metode purposive sampling. Menurut Sugiyono (2005) Purposive 
Sampling yaitu tekhnik penentuan sampel berdasarkan pertimbangan - pertimbangan tertentu. Populasi yang akan menjadi sampel akan dilihat dari kriteria yang ditentukan. Adapun kriteria untuk mahasiswa dan mahasiswi D3 MP FEKONSOS Universitas Islam Negeri Sultan Syarif Kasim Riau adalah mahasiswa dan mahasiswi D3 MP semester III dan V. Jumlah mahasiswa dan mahasiswi tersebut yaitu 119 orang, dikarenakan populasi berjumlah 119 orang maka peneliti menjadikan semua populasi sebagai sampel penelitian. Sampel tersebut terdiri dari mahasiswa 58 orang dan mahasiswi dengan jumlah 61 orang.

\subsection{Metode Pengumpulan Data.}

Data yang akan digunakan dalam penelitiaan ini adalah data primer dan data sekunder.

a. Data primer yaitu data yang diambil langsung dari sumber aslinya (tidak melalui media perantara). Dalam hal ini data primer tersebut berupa opini dari responden yang menjadi obyek penelitiaan.

b. Sedangkan, data sekunder adalah data yang diperoleh melalui studi pustaka, yaitu mengumpulkan data yang dipakai untuk penyusunan landasan teori dengan cara mempelajari buku - buku makalah dan artikel yang berhubungan dengan penelitian

Strategi pengumpulan data yang digunakan adalah strategi opini untuk mendapatkan opini individu dengan menggunakan metode survei. Metode survei adalah teknik pengumpulan dan analisa data berupa kuesioner. Kuesioner dalam penelitiaan ini berisi daftar pernyataan berupa angket yang disebarkan kepada responden untuk mengumpulkan fakta - fakta berupa pendapat, perasaan, dan keinginan.

Kuesioner ini disebarkan secara langsung oleh peneliti kepada responden. Selain menggunakan alat bantu kuesioner, peneliti juga melakukan wawancara atau tanya jawab secara langsung dengan para responden guna mendapatkan data dan keterangan yang menunjang penelitiaan.

\subsection{Pengembangan Instrumen Penelitian.}

Instrumen penelitiaan yang digunakan adalah kuesioner yang berisi pernyataanpernyataaan sederhana yang jawabannya dapat digunakan untuk mengetahui persepsi mahasiswa Jurusan Akuntansi Universitas Islam Negeri Sultan Syarif Kasim Riau terhadap fakor- faktor pemicu kecurangan. Kuesioner yang digunakan dalam penelitian ini dikembangkan sendiri oleh peneliti dan terbagi menjadi dua bagian, yaitu:

a. Bagian pertama yang berisikan latar belakang yang ditujukan untuk mengidentifikasi dan mengelompokkan responden. Dalam mengembangkan bagiaan ini, peneliti mempelajari bentuk - bentuk kuesioner yang ada dan melakukan seleksi untuk memilih item - item mana saja yang terkait dan diperlukan dalam penelitian ini.

b. Bagian kedua berisi persepsi responden terhadap fakor- faktor pemicu kecurangan yang diukur menggunakan skala likert 3 kategori. Dalam 
mengembangkan bagian ini, peneliti membuat ilustrasi yang memasukkan unsur - unsur tindak pidana korupsi seperti yang tertuang dalam buku Memahami Untuk Membasmi yamg ditulis oleh Komisi Pemberantasan Korupsi (2006). Disamping itu, peneliti juga mempertimbangkan saran dari temen-teman dosen lain dalam mengembangkan bagian ini.

\subsection{Pengujian Kualitas Data.}

Penelitian yang mengukur variabel dengan mengunakan instrumen dalam kuesioner harus diuji kualitas data tersebut dengan uji validitas dan reliabilitas. Hal ini dimaksudkan untuk mengetahui apakah instrumen tersebut valid dan sahih atau reliabel, untuk mengukur variabel yang akan diukur sehingga penelitian ini bisa mendukung hipotesis yang akan diajukan.

\section{a. Uji Validitas}

Untuk menilai kevalitan tiap butir - butir pertanyaan dapat dilihat dari Corrected item - Total Correlation. Sugiyono (2007) menyatakan bahwa suatu item kuesioner dapat dikatakan valid jika Corrected item - Total Correlation memiliki nilai kritis $>0,3$ atau $30 \%$. Dengan demikian bahwa item yang memiliki korelasi $>30 \%$ dikategorikan valid, sedangkan item yang memiliki korelasi $<30 \%$ maka dikatakan tidak valid.

\section{b. Uji Reliabilitas}

Kriteria yang digunakan dalam penelitian ini adalah one shot, artinya satu kali pengukuran saja dan kemudian hasilnya dibandingkan dengan pertanyaan lainnya. Pada program SPSS reabilitas dilakukan dengan uji statistik Cronbach Alpha $(\alpha)$. Suatu konstruk dikatakan reliabel jika memberikan nilai > 0,60 (Nunnally dalam Imam Ghozali : 2005).

\section{c. Uji Normalitas}

Pada penelitian ini untuk menguji normalitas data menggunakan uji One Sample Kolmogorov-Smirnov, kriteria yang digunakan adalah jika masing-masing variabel menghasilkan nilai K-S-Z dengan menggunakan taraf signifikansi 0,05, maka dapat disimpulkan bahwa masing-masing data pada variabel yang diteliti berdistribusi secara normal jika signifikansi lebih besar dari $5 \%$ atau 0,05 .

\subsection{Teknik Pengujian Data dan Teknik Pengujian Hipotesis. \\ a. Pengujian Data.}

Sebelum dianalisis, maka dilakukan pengolahan data terlebih dahulu. Pengolahan data adalah suatu proses dalam memperoleh data ringkasan atau angka ringkasan dengan menggunakan cara - cara atau rumus - rumus tertentu.

Untuk memudahkan tabulasi peneliti menggunakan bantuan program SPSS (Statistical Package for Sosial Science). Setelah melalui tahap pengolahan data maka dilakukan tahap pengujian hipotesis. 


\section{b. Teknik Pengujian Hipotesis.}

Hipotesis ini didasarkan atas keiniginan untuk menarik kesimpulan atau fenomena yang sedang diteliti yaitu apakah mahasiswa dan mahasiswi Jurusan D3 MP Fakultas Ekonomi Universitas Islam Negeri Sultan Syarif Kasim Riau memiliki persepsi yang berbeda terhadap faktor-faktor pemicu kecurangan.

Adapun analisis yang digunakan dalam penelitian ini adalah independen sample $\mathrm{T}$ Tes. Uji beda $\mathrm{T}$ tes independen bertujuan untuk menentukan apakah dua sampel yang tidak berhubungan satu dengan yang lainnya mempunyai nilai rata - rata yang sama atau tidak secara signifikan. Uji beda $\mathrm{T}$ Tes independen dilakukan dengan cara membandingkan perbedaan antara dua nilai perbedaan rata - rata dengan standar error dari perbedaan rata-rata dua sampel atau dapat dituliskan dengan rumus :

$\mathrm{t}=\underline{\text { Rata }- \text { rata sampel pertama }- \text { rata }- \text { rata sampel kedua }}$

Standar error perbedaan rata - kedua sampel.

Langkah awal penelitian adalah melakukan uji dengan melihat pada kesamaan atau perbedaan nillai rata - rata jawaban responden. Selain itu melihat pada kesamaan atau perbedaan nilai varian dan mean masing - masing responden .Untuk menerima atau menolak hipotesis dapat mengacu pada kriteria di bawah ini:

a. Jika probabilitas $>0,05$, maka Ho di terima, artinya kelompok memiliki varian yang sama.

b. Jika probabilitas < 0,05, maka Ho ditolak, artinya kelompok memilki varian yang berbeda.

Setelah mengetahui ada atau tidaknya perbedaan nilai mean, ada dua tahapan analisis yang harus dilakukan berikutnya, yaitu 1) harus menguju asumsi apakah varian populasi kedua sampel tersebut sama (equal variances assumed) atau perbedaan (equal variances not assumed) dengan melihat nilai levene tes. Setelah diketahui apakah varian sama atau tidak, maka ke 2) melihat nilai $\mathrm{t}=$ tes untuk menentukan apakah terdapat perbedaan nilai rata - rata secara signifikan.

Rumusan hipotesis dalam penelitian ini adalah:

$$
\begin{aligned}
& \text { 1. } \mathrm{Ha} 1=\mu_{1} \# \mu_{2} \\
& \text { 2. } \mathrm{Ha} 2=\mu_{1} \# \mu_{2} \\
& \text { 3. } \mathrm{Ha} 3=\mu_{1} \# \mu_{2} \\
& \text { 4. } \mathrm{Ha} 4=\mu_{1} \# \mu_{2}
\end{aligned}
$$

Keterangan :

$\mu_{1}=$ Rata - rata persepsi mahasiswa D3 MP yang berjenis kelamin laki - laki.

$\mu_{2}=$ Rata - rata persepsi mahasiswa D3 MP yang berjenis kelamin perempuan. 


\section{BAB IV \\ HASIL PENELITIAN \& PEMBAHASAN}

\subsection{Statistik Deskriptif}

Teknik pengumpulan data telah dijelaskan pada bab sebelumnya, bahwa sampel keseluruhan dari penelitian yaitu sebanyak 119 orang, yaitu yang terdiri dari 58 orang jenis kelamin laki-laki dan 61 orang jenis kelamin perempuan jurusan Diploma III Manajemen Perusahaan Universitas Islam Negeri Sultan Syarif Kasim Riau mahasiswa semester III dan V.

Analisa data selanjutnya yaitu statistik deskriptif dengan jumlah jenis kelamin laki-laki sebanyak 46 responden jurusan Diploma III Manajemen Perusahaan Universitas Islam Negeri Sultan Syarif Kasim Riau yang memenuhi kriteria untuk dapat diolah. Hasil pengolahan data statistik deskriptif ditunjukkan pada tabel IV.1 dibawah ini:

\section{Tabel IV.1 Statistik Deskriptif jenis kelamin Laki-laki}

\section{Descriptive Statistics}

\begin{tabular}{|c|c|c|c|c|c|}
\hline & $\mathrm{N}$ & $\underset{\mathrm{m}}{\operatorname{Minimu}}$ & $\begin{array}{l}\text { Maxim } \\
\text { um }\end{array}$ & Mean & $\begin{array}{c}\text { Std. } \\
\text { Deviation }\end{array}$ \\
\hline PRESSURE & 46 & 5 & 15 & 8.67 & 2.805 \\
\hline $\begin{array}{l}\text { OPPURTUNIT } \\
\text { TY }\end{array}$ & 46 & 5 & 13 & 7.43 & 2.197 \\
\hline $\begin{array}{l}\text { RATIONALIZ } \\
\text { ATIONS }\end{array}$ & 46 & 5 & 15 & 10.33 & 3.004 \\
\hline FRAUD & 46 & 5 & 15 & 12.28 & 2.722 \\
\hline $\begin{array}{l}\text { Valid N } \\
\text { (listwise) }\end{array}$ & 46 & & & & \\
\hline
\end{tabular}

Sumber : Data olahan tahun 2016

Dalam tabel IV.2 terlihat bahwa variabel pressure dengan jumlahresponden sebanyak 46 mempunyai nilai minimum sebesar 5, nilai maksimum yaitu sebesar 15, dan nilai rata-rata sebesar 8,67. Jika jawaban rata-rata responden lebih tinggi dari 8,67, maka responden tersebut menyatakan bahwa tekanan yang diterima oleh pelaku kecurangan lebih besar.

Variabel oppurtunitty mempunyai nilai minimum sebesar 5, nilai maksimum sebesar 13, dan nilai rata-rata sebesar 7,43. Jika jawaban rata-rata responden lebih tinggi dari 7,43, maka responden tersebut menyatakan bahwa kesempatan yang diambil oleh pelaku kecurangan lebih besar.

Variabel rationalizations mempunyai nilai minimum sebesar 5, nilai maksimum sebesar 15, dan nilai rata-rata sebesar 10,33. Jika jawaban rata-rata responden lebih tinggi dari 10,33, maka responden tersebut menyatakan bahwa rasional yang salah oleh pelaku kecurangan lebih besar.

Variabel fraud mempunyai nilai minimum sebesar 5, nilai maksimum sebesar 15 , dan nilai rata-rata sebesar 12,28 . Jika jawaban rata-rata responden lebih tinggi dari 
12,28, maka responden tersebut menyatakan bahwa kecurangan yang dilakukan oleh pelaku kecurangan lebih besar.

Sedangkan hasil pengolahan statistik deskriptif terhadap 54 responden jenis kelamin perempuan jurusan Diploma III Manajemen Perusahaan Universitas Islam Negeri Sultan Syarif Kasim Riau yang memenuhi kriteria untuk dapat diolah. Hasil pengolahan data statistik deskriptif ditunjukkan pada tabel IV.2 dibawah ini:

\section{Tabel IV.2 Statistik Deskriptif jenis kelamin Perempuan}

\section{Descriptive Statistics}

\begin{tabular}{|c|c|c|c|c|c|}
\hline & $\mathrm{N}$ & $\begin{array}{c}\text { Minim } \\
\text { um }\end{array}$ & $\begin{array}{l}\text { Maxi } \\
\text { mum }\end{array}$ & Mean & $\begin{array}{c}\text { Std. } \\
\text { Deviation }\end{array}$ \\
\hline PRESSURE & 54 & 5 & 15 & 10.30 & 3.248 \\
\hline $\begin{array}{l}\text { OPPURTUNIT } \\
\text { TY }\end{array}$ & 54 & 5 & 15 & 9.37 & 3.498 \\
\hline $\begin{array}{l}\text { RATIONALIZ } \\
\text { ATIONS }\end{array}$ & 54 & 5 & 15 & 9.94 & 2.949 \\
\hline FRAUD & 54 & 5 & 15 & 12.15 & 3.165 \\
\hline $\begin{array}{l}\text { Valid N } \\
\text { (listwise) }\end{array}$ & 54 & & & & \\
\hline
\end{tabular}

Sumber : Data olahan tahun 2016

Dalam tabel IV.3 terlihat bahwa variabel pressure dengan jumlah respondennya sebanyak 54 mempunyai nilai minimum sebesar 5 , nilai maksimum sebesar 15, dan nilai rata-rata sebesar 10,30. Jika jawaban rata-rata responden lebih tinggi dari 10,30, maka responden tersebut menyatakan bahwa tekanan yang diterima oleh pelaku kecurangan lebih besar.

Variabel oppurtunitty mempunyai nilai minimum sebesar 5, nilai maksimum sebesar 15, dan nilai rata-rata sebesar 9,37. Jika jawaban rata-rata responden lebih tinggi dari 9,37, maka responden tersebut menyatakan bahwa kesempatan yang diambil oleh pelaku kecurangan lebih besar.

Variabel rationalizations mempunyai nilai minimum sebesar 5, nilai maksimum sebesar 15, dan nilai rata-rata sebesar 9,94. Jika jawaban rata-rata responden lebih tinggi dari 9,94, maka responden tersebut menyatakan bahwa rasional yang salah oleh pelaku kecurangan lebih besar.

Variabel fraud mempunyai nilai minimum sebesar 5, nilai maksimum sebesar 15 , dan nilai rata-rata sebesar 12,15 . Jika jawaban rata-rata responden lebih tinggi dari 12,15 , maka responden tersebut menyatakan bahwa kecurangan yang dilakukan oleh pelaku kecurangan lebih besar.

\subsection{Analisis Data Penelitian}

\subsubsection{Hasil Uji Validitas dan Reliabilitas Data}

Penelitian yang mengukur variabel dengan menggunakan instrument dalam kuesioner harus diuji kualitas datanya atau syarat yang penting yang berlaku dalam kuesioner seperti: keharusan suatu kuesioner untuk valid dan reliabel. Hal ini 
dimaksudkan untuk mengetahui apakah instrumen tersebut valid dan reliabel untuk variabel yang akan diukur, sehingga penelitian ini bisa mendukung hipotesis.

Validitas data yang ditentukan oleh proses pengukuran yang kuat. Suatu instrumen pengukuran dikatakan mempunyai validitas yang kuat apabila instrumen tersebut mengukur apa yang sebenarnya diukur. Uji validitas digunakan untuk mengetahui item-item yang ada di dalam kuesioner yang mana manpu mengukur dan mengubah yang diperoleh dalam penelitian. Untuk mengetahui valid atau tidaknya suatu variabel yaitu ditentukan dari pengujian dengan menggunakan teknik correlate bivariate dengan nilai korelasi diatas 0,30.

Sedangkan uji reliabilitas digunakan untuk mengetahui instrumen penelitian dimana kriteria yang digunakan adalah one shot, artinya satu kali pengukuran saja dan kemudian hasinya dibandingkan dengan pernyataan lainnya. Pada program SPSS riabilitas dilakukan dengan uji statistik Cronbach Alpha. Suatu konstruk dikatakan reliabel jika memberikan nilai > 0,70 (Nunnally dalam Imam Ghazali : 2005). Rekapitulasi hasil uji validitas dan uji reliabilitas semua variabel terlihat pada tabel IV. 3 berikut ini:

Tabel IV.3 Hasil Uji Validitas dan Relibilitas

\begin{tabular}{|c|c|c|c|c|}
\hline \multirow{2}{*}{$\begin{array}{l}\text { Item } \\
\text { Variabel }\end{array}$} & \multicolumn{2}{|c|}{ Validitas } & \multicolumn{2}{|c|}{ Reliabilitas } \\
\hline & $\begin{array}{c}\text { Pearson } \\
\text { Correlat } \\
\text { ion }\end{array}$ & $\begin{array}{c}\text { Kesimp } \\
\text { ulan }\end{array}$ & $\begin{array}{c}\text { Cronba } \\
\text { ch } \\
\text { Alpha }\end{array}$ & $\begin{array}{c}\text { Keputu } \\
\text { san }\end{array}$ \\
\hline \multicolumn{5}{|l|}{$\begin{array}{l}\text { Pressur } \\
e\end{array}$} \\
\hline X1.1 & 0,919 & Valid & & \\
\hline $\mathrm{X} 1.2$ & 0,525 & Valid & & \\
\hline $\mathrm{X} 1.3$ & 0,762 & Valid & 0,824 & Reliabel \\
\hline $\mathrm{X} 1.4$ & 0,877 & Valid & & \\
\hline $\mathrm{X} 1.5$ & 0,777 & Valid & & \\
\hline \multicolumn{5}{|l|}{$\begin{array}{l}\text { Oppurtun } \\
\text { itty }\end{array}$} \\
\hline X2.1 & 0,899 & Valid & & \\
\hline $\mathrm{X} 2.2$ & 0,783 & Valid & & \\
\hline $\mathrm{X} 2.3$ & 0,920 & Valid & $\mathbf{0 , 8 5 0}$ & $\begin{array}{c}\text { Relia } \\
\text { bel }\end{array}$ \\
\hline $\mathrm{X} 2.4$ & 0,598 & Valid & & \\
\hline $\mathrm{X} 2.5$ & 0,742 & Valid & & \\
\hline \multicolumn{5}{|l|}{$\begin{array}{l}\text { Rationaliz } \\
\text { ations }\end{array}$} \\
\hline X3.1 & 0,695 & Valid & & \\
\hline X3.2 & 0,715 & Valid & & \\
\hline X3.3 & 0,768 & Valid & 0,738 & Reliabel \\
\hline X3.4 & 0,648 & Valid & & \\
\hline $\mathrm{X} 3.5$ & 0,668 & Valid & & \\
\hline \multicolumn{5}{|l|}{ Fraud } \\
\hline $\mathrm{X} 4.1$ & 0,765 & Valid & & \\
\hline $\mathrm{X} 4.2$ & 0,905 & Valid & & \\
\hline $\mathrm{X} 4.3$ & 0,767 & Valid & $\mathbf{0 , 8 0 2}$ & Reliabel \\
\hline
\end{tabular}




\begin{tabular}{|l|l|l|l|l|}
\hline X4.4 & 0,505 & Valid & & \\
\hline X4.5 & 0,769 & Valid & & \\
\hline
\end{tabular}

Sumber : Data olahan tahun 2016

Dari tabel IV.4 dapat dijelaskan bahwa persepsi mahasiswa jurusan Diploma III Manajemen Perusahaan Universitas Islam Negeri Sultan Syarif Kasim Riau terhadap faktor-faktor pemicu kecurangan diukur dengan 20 item pertanyaan yang terdiri dari:

1. Pressure diukur dengan 5 item pertanyaan. Setelah dilakukan uji reliabilitasnya, nilai koefisien Alpha adalah 0,824 yang berarti variabel tersebut reliabel dengan keputusan baik, karena memiliki nilai koefisien Alpha diatas 0,70 . Hasil uji validitas menunjukkan nilai korelasi yang terendah yaitu 0,525 , artinya semua item variabel di atas 0,30 dan memenuhi syarat untuk valid.

2. Oppurtunitty diukur dengan 5 item pertanyaan. Setelah dilakukan uji reliabilitasnya, nilai koefisien Alpha adalah 0,850 yang berarti variabel tersebut reliabel dengan keputusan baik, karena memiliki nilai koefisien Alpha di atas 0,70. Sedangkan hasil uji validitas menunjukkan nilai korelasi yang terendah yaitu 0,598, artinya semua item variabel di atas 0,30 dan memenuhi syarat untuk valid.

3. Rationalizations diukur dengan 5 item pertanyaan. Setelah dilakukan uji reliabilitasnya, nilai koefisien Alpha adalah 0,738 yang berarti variabel tersebut reliabel dengan keputusan baik, karena memiliki nilai koefisien Alpha di atas 0,70 . Sedangkan hasil uji validitas menunjukkan nilai korelasi yang terendah yaitu 0,648 , artinya semua item variabel di atas 0,30 dan memenuhi syarat untuk valid.

4. Fraud diukur dengan 5 item pertanyaan. Setelah dilakukan uji reliabilitasnya, nilai koefisien Alpha adalah 0,802 yang berarti variabel tersebut reliabel dengan keputusan baik, karena memiliki nilai koefisien Alpha di atas 0,70. Sedangkan hasil uji validitas menunjukkan nilai korelasi yang terendah yaitu 0,505 , artinya semua item variabel di atas 0,30 dan memenuhi syarat untuk valid.

\subsubsection{Analisis Uji Normalitas}

Pada penelitian ini untuk menguji normalitas data menggunakan uji One Sample Kolmogorov-Smirnov, kriteria yang digunakan adalah jika masing-masing variabel menghasilkan nilai K-S-Z dengan menggunakan taraf signifikansi 0,05, maka dapat disimpulkan bahwa masing-masing data pada variabel yang diteliti berdistribusi secara normal jika signifikansi lebih besar dari 5\% atau 0,05. Hasil uji normalitas mahasiswa disajikan sebagai berikut : Nilai K-S-Z untu k variabel Pressure adalah sebesar 1,127 dengan signifikansi 0,184. Nilai K-S-Z untuk variabel Oppurtunitty adalah sebesar 1,244 dengan nilai signifikan sebesar 0,101. Niai K-S-Z untuk variabel Rasionalizations adalah sebesar 1,138 dengan signifikansi sebesar 0,150 dan untuk nilai K-S-Z untuk variabel Fraud adalah sebesar 1,148 dengan signifikansi sebesar 0,074, maka dapat disimpulkan bahwa data pada variabel pressure, oppurtunitty, rasiolalizations dan fraud berdistribusi normal. 
Sedangkan hasil uji normalitas mahasiswi disajikan sebagai berikut : Nilai KS-Z untuk variabel Pressure adalah sebesar 1,174 dengan signifikansi 0,127. Nilai KS-Z untuk variabel Oppurtunitty adalah sebesar 0,941 dengan nilai signifikan sebesar 0,339. Niai K-S-Z untuk variabel Rasionalizations adalah sebesar 0,891 dengan signifikansi sebesar 0,405 dan untuk nilai K-S-Z untuk variabel Fraud adalah sebesar 1,268 dengan signifikansi sebesar 0,082, maka dapat disimpulkan bahwa data pada variabel pressure, oppurtunitty, rasiolalizations dan fraud berdistribusi normal.

Dari tabel IV.5 Dan IV.6 diatas maka didapat nilai signifikansi K-S-Z dari masingmasing variabel rata-rata >0,05, maka dapat diambil keputusan bahwa variabel pressure, oppurtunitty, rationalizations dan fraud secara statistik telah berdistribusi secara normal dan layak digunakan sebagai data penelitian.

\subsection{Pengujian Hipotesis dan Pembahsan Uji Independent Sample T-Test}

Uji ini digunakan untuk mengetahui ada atau tidaknya perbedaan rata-rata antara dua kelompok sampel yang tidak berhubungan. Jika ada perbedaan, rata-rata manakah yang lebih tinggi. Data yang digunakan biasanya berskala interval atau rasio. Hasil uji beda independent sample T-Test yaitu

1. Ha1 : Terdapat perbedaan persepsi antara mahasiswa Jurusan Diploma III Manajemen Perusahaan Universitas Islam Negeri Sultan Syarif Kasim Riau yang berjenis kelamin laki-laki dan perempuan terhadap pressure.

Nilai signifikan pada variabel pressure adalah 0,009, nilai ini lebih kecil dari pada 0,05 yang menunjukkan bahwa $\mathrm{Ha}_{1}$ DITERIMA. Hasil ini menunjukkan bahwa terdapat perbedaan persepsi antara mahasiswa Jurusan Diploma III Manajemen Perusahaan Universitas Islam Negeri Sultan Syarif Kasim Riau yang berjenis kelamin laki-laki dan berjenis kelamin perempuan terhadap pressure.

Pressure adalah tekanan yang diterima oleh pelaku kecurangan yang dapat berupa tekanan keuangan, sekunder, pekerjaan dan tekanan lainnya. Tekanan keuangan dikarenakan adanyan sifat serakah dalam diri seseorang yang mendorong dirinya untuk tidak pernah puas dan selalu berusaha memiliki sesuatu melebihi orang lain dengan cara apapun. Tekanan sekunder dapat dikarenakan oleh ketagihan, baik ketagihan karena judi, obat terlarang maupun minuman keras. Tekanan pekerjaan disebabkan ketidakpuasan atas pekerjaan, kurangnya pengakuan atas kinerja, adanya perasaan takut kehilangan pekerjaan, tidak mendapat promosi dan merasa digaji rendah. Sedangkan ketidakmampuan seseorang untuk membedakan antara kebutuhan dengan keinginan dan kebiasaan sebagaian besar orang untuk megukur kesuksesan tidak berdasarkan pada integritas dan kejujuran seseorang dalam bekerja.

Dengan deterimanya hipotesis diatas maka dapat diputuskan persepsi mahasiswa dan mahasiswi berbeda akan pemahaman tentang tekanan yang diterima oleh pelaku kecurangan.

2. Ha2 : Terdapat perbedaan persepsi antara mahasiswa Jurusan Diploma III Manajemen Perusahaan Universitas Islam Negeri Sultan Syarif Kasim Riau yang berjenis kelamin laki-laki dan perempuan terhadap oppurtunitty. 
Nilai signifikan pada variabel oppurtunitty adalah 0,002, nilai ini lebih kecil dari pada 0,05 yang menunjukkan bahwa $\mathrm{Ha}_{2}$ DITERIMA. Hasil ini menunjukkan bahwa terdapat perbedaan persepsi antara mahasiswa Jurusan Diploma III Manajemen Perusahaan Universitas Islam Negeri Sultan Syarif Kasim Riau yang berjenis kelamin laki-laki dan berjenis kelamin perempuan terhadap oppurtunitty.

Oppurtunittyadalah kesempatan yang dapat diambil oleh pelaku kecuragan. Kesempatan ini muncul sebagai akibat dari curangnya atau adanya pengelakan terhadap pengendalian untuk mencegah dan mendeteksi perilaku kecurangan, adanya ketidakmampuan untuk menilai kualitas kinerja, adanya kegagalan untuk mendisiplinkan pelaku kecurangan, adanya keterbatasan untuk mengakses informasi, adanya kebodohan, kemalasan dan ketidakmampuan serta kurangnya audit trail. Seseorang yang memiliki sifat oportunis tentu saja tidak akan meyia-nyiakan kesempatan ini untuk melakukan kecurangan dan mendapatkan keuntungan dari perilakunya itu.

Dengan diterimanya hipotesis diatas maka dapat diputuskan persepsi mahasiswa dan mahasiswi berbeda akan pemahaman tentang kesempatan yang dapat diambil oleh pelaku kecurangan.

\section{Ha3 : Terdapat perbedaan persepsi antara mahasiswa Jurusan Diploma III Manajemen PerusahaanUniversitas Islam Negeri Sultan Syarif Kasim Riau yang berjenis kelamin laki-laki dan perempuan terhadap rationalizations}

Nilai signifikan pada variabel rationalizationsadalah 0,524 nilai ini lebih besar dari 0,05 yang menunjukkan bahwa $\mathrm{Ha}_{3}$ DITOLAK. Hasil ini menunjukkan bahwa tidak terdapat perbedaan persepsi antara mahasiswa Jurusan Diploma III Manajemen PerusahaanUniversitas Islam Negeri Sultan Syarif Kasim Riau yang berjenis kelamin laki-laki dan berjenis kelamin perempuan terhadap rationalizations.

Rationalizations adalah adanya rasionalisasi yang salah oleh pelaku kecurangan. Pelaku kecurang biasanya memiliki rasionalisasi yang berusaha untuk membenarkan tindakannya tersebut. Rasionalisasi yang biasa digunakan oleh pelaku kecurangan diantaranya bahwa perusahaan memberikan hutang kepada pelaku, pelaku hanya meminjam uang tersebut dan akan ia kembalikan, tidak akan ada yang terluka, pelaku pantas untuk mendapat lebih, kecurangan dilakukan untuk tujuan yang baik, pelaku akan memperbaiki pembukuan secepatnya setelah kesulitan keuangan berakhir, atau ada sesuatu yang harus dikorbankan-integritas atau reputasi pelaku. Ketika seseorang dituntut untuk berfikir rasional pada apa yang telah diperbuat dan tidak pula langsung menyalahkan apa yang telah dikerjakan.

Dengan ditolaknya hipotesis diatas maka dapat diputuskan bahwa persepsi mahasiswa dan mahasiswi tidaklah berbeda akan pemahaman tentang adanya rasionalisasi yang salah oleh pelaku kecurangan.

4. Ha4 : Terdapat perbedaan persepsi antara mahasiswa Jurusan Diploma III Manajemen Perusahaan Universitas Islam Negeri Sultan Syarif Kasim Riau yang berjenis kelamin laki-laki dan perempuan terhadap fraud. 
Nilai signifikan pada variabel fraud adalah 0,822 nilai ini lebih besar dari 0,05 yang menunjukkan bahwa Ha ${ }_{4}$ DITOLAK. Hasil ini menunjukkan bahwa tidak terdapat perbedaan persepsi antara mahasiswa Jurusan Diploma III Manajemen PerusahaanUniversitas Islam Negeri Sultan Syarif Kasim Riau yang berjenis kelamin laki-laki dan berjenis kelamin perempuan terhadapfraud.

Fraud adanya pemberian manfaat keuangan kepada si penipu kecurangan, disini berarti setiap tindakan merupakan kesalahan serius yang dilakukan dengan menggunakan akal fikiran manusia untuk menipu dan menyembunyikan kebenaran diri serta melakukan kelicikan. Dari tindakan jahat tersebut pelaku memperoleh manfaat dan merigukan korbannya secara financial. Menurut Albercht (2003), pelaku kecuranga biasanya memiliki karakteristik yang sama dengan kebanyakan orang pada umumnya. Bahkan sebagian besar pelaku kecuranganjustru tampak seperti orang-orang yang berprilaku jujur.

Para pelaku kecurangan pada umumnya memiliki pendidikan yang tinggi dan lebih beragama, sedikit atau bahkan tidak memiliki catatan kejahatan dan bukan pula pecandu alkihol maupun obat terlarang. Berdasarkan karakteristik tersebut, sebagian besar karyawan, pelanggan, vedor dan rekan bisnis maupun pihak-pihak yang memenuhi karakteristik tersebut sehingga membuat mereka memiliki kemungkinan untuk melakukan kecurangan.

Dengan ditolakknya hipotesis diatas maka dapat diputuskan bahwa persepsi mahasiswa dan mahasiswi tidaklah berbeda ataupun identik akan pemahaman tentang kecurangan yang dilakukan oleh pelaku kecurangan

\section{BAB V KESIMPULAN DAN SARAN}

\subsection{Kesimpulan}

Tujuan penelitian ini adalah untuk menguji apakah terdapat perbedaan persepsi antara mahasiswa dan mahasiswi Jurusan Diploma III Manajemen Perusahaan Universitas Islam Negeri Sultan Syarif Kasim Riau terhadap faktor-faktor pemicu kecurangan yaitu pressure, oppurtunitty, rationalizations dan fraud.

Dari hasil pengujian hipotesis dengan menggunakan uji Independent Sample TTest yang telah dijelaskan pada bab IV dapat disimpulkan sebagai berikut:

1. Berdasarkan statistik t hitung sebesar -2,649 dengan nilai signifikan pada variabel pressure adalah 0,009 nilai ini lebih kecil dari pada 0,05. Hasil ini menunjukkan bahwa terdapat perbedaan persepsi antara mahasiswa Jurusan D3 MP Universitas Islam Negeri Sultan Syarif Kasim Riau yang berjenis kelamin laki-laki dan berjenis kelamin perempuan terhadap pressure.

2. Berdasarkan statistik t hitung sebesar $-3,245$ dengan nilai signifikan pada variabel oppurtunitty adalah 0,002 nilai ini lebih kecil dari pada 0,05. Hasil ini menunjukkan bahwa terdapat perbedaan persepsi antara mahasiswa Jurusan D3 MP Universitas Islam Negeri Sultan Syarif Kasim Riau yang berjenis kelamin lakilaki dan berjenis kelamin perempuan terhadap oppurtunitty. 
3. Berdasarkan statistik t hitung sebesar 0,640 dengan nilai signifikan pada variabel rationalizationsadalah 0,524 nilai ini lebih besar dari pada 0,05. Hasil ini menunjukkan bahwatidak terdapat perbedaan persepsi antara mahasiswa Jurusan D3 MP Universitas Islam Negeri Sultan Syarif Kasim Riau yang berjenis kelamin laki-laki dan berjenis kelamin perempuan terhadap rationalizations.

4. Berdasarkan statistik thitung sebesar 0,226 dengan nilai signifikan pada variabel fraud adalah 0,822 nilai ini lebih besar dari pada 0,05. Hasil ini menunjukkan bahwa tidak terdapat perbedaan persepsi antara mahasiswa Jurusan D3 MP Universitas Islam Negeri Sultan Syarif Kasim Riau yang berjenis kelamin laki-laki dan berjenis kelamin perempuan terhadap fraud.

\subsection{Keterbatasan}

Peneliti mengakui bahwa penelitian ini masih jauh dari kesempurnaan dan masih terdapat keterbatasan-keterbatasan yang ada. Beberapa keterbatasan dalam penelitian ini antara lain:

1. Faktor-faktor pemicu kecurangan yang digunakan untuk menguji persepsi mahasiswa Diploma III Manajemen Perusahaan Universitas Islam Negeri Sultan Syarif Kasim Riau dalam penelitian ini hanya terbatas pada pressure, oppurtunitty, rationalizations dan fraud. Untuk penelitian selanjutnya diharapkan bisa menambahkan unsur-unsur lain yang dianggap penting.

2. Responden yang digunakan dalam penelitian ini masih sedikit dan hanya terfokus pada mahasiswa Diploma III Manajemen Perusahaan UIN Suska Riau.

\subsection{Saran} antara lain :

Berdasarkan hasil penelitian yang telah dilakukan maka diajukan saran,

1. Untuk mengurangi pemicu kecurangan kita mesti meningkatkan kejujuran,yaitu haruslah dimulai dari diri sendiri. Jika seseorang itu sadar bahwa curang itu sangat merugikan orang lain yang tidak bersalah, maka sudah semestinya untuk dihindari.

2. Untuk peneliti selanjutnya, agar menggunakan faktor-faktor lain yang mempengaruhi pemicu kecurangan untul lebih menambah wawasan penelitian.

\section{DAFTAR PUSTAKA}

Albrecht, W. Steve, 2003, Fraud Examination, Thomson South - Westren, USA

Amrizal, 2004, Pencegahan dan Pendeteksian Kecurangan oleh International Auditor, Jakarta 
Komisi Pemberantsan Korupsi,2006, Memahami Untuk Membasmi Buku Saku Untuk Memahami Tindakkan Pidana Korupsi, Cetakan Kedua, Jakarta.

Kotler, Phillip, 2009, Manajemen Pemasaran, Buku Satu, Terjemahan, PT. Indeks, Jakarta.

Ghozali, Imam, 2005, Aplikasi Analisis Multivariabel dengan Proggram SPSS, Edisi 3, Badan Penerbit Universitas Diponegoro, Semarang.

Kreitner, R dan Angelo Kinicki, 2003, Prilaku Organisasi, Buku satu, Terjemahan, Penerbit Salemba Empat, Jakarta.

Santoso, Singgih. 2001. SPSS Statistik Parametrik. Jakarta: PT Elex Media Komputindo, Gramedia.

Suprianto, 2006, Banyaknya Perusahaan Buat Laporan Keuangan Ganda, Tempo,31, Juli.

Talib, 2006, Persepsi atas Unetichal Behaviour dalam Sistem Informasi Faktor Gender dan Jurusan Studi, (S-1), Jurusan Akuntansi Fakultas Ekonomi Universitas Brawijaya, Malang

Tuanakotta, Theodorus, 2006, Forensic Accounting, Kuliah Tamu, Fakultas Ekonomi Universitas Riau, Pekanbaru.

Vorhof, Kristen, 2004, The Integry of Our Country, Association of Fraud Examiner (ACFE) Article, October (diakses online dari www.acfe.com)

Sugiyono, Metode Penelitian Bisnis, Bandung Alfabeta, 2007

Wells, Joseph, T. 2003, The Reward of Dishosnesty, Association of Fraud Examiner (ACFE) Article, March (diakses online dari www.acfe.com)

Wibowo, 2006, Ekplorasi atas Praktek Kecurangan Akademik (Cheating), Skripsi (S1), Jurusan Akuntansi Fakultas Ekonomi Universitas Brawijaya, Malang 